\title{
Quality Analysis of Infrastructure and Environmental Needs in CSR Activities of PT Indonesia Power Semarang Power Generation Unit
}

\author{
Muchamad Yuliyanto \\ \{yuliyanto@undip.ac.id\} \\ Universitas Diponegoro, Indonesia
}

\begin{abstract}
PT Indonesia Power Semarang as a state company in the middle of society has a social responsibility (Corporate Social Responsibility) to the surrounding environment. CSR can be realized in the form of assistance providing infrastructure needs and community environment to build relationships with conducive communities and support each other's community progress and company existence. The approaches from this research are descriptive-quantitative and use methods survey, population are citizen in Gunungpati area, Semarang city. Then samples of research they receive aids from CSR programmed are a hundred persons. Unit of analysis in research are aids infrastructure and environmental needs to citizen. The assistance activities can be evaluated by quality analysis with response indicators from community members. Outcome from research explains about infrastructure and environmental need in CSR of PT Indonesia power Semarang is good and very use by citizen in Gunungpati, Semarang city.
\end{abstract}

Keywords: CSR, Infrastructure and Environmental Needs, Quality Analysis

\section{Introduction}

Corporate social responsibility is the form and contribution of the company to the sustainability of the life of the surrounding community, the activity to show commitment to social, economic, infrastructure and environmental issues. Corporate Social Responsibility (CSR) activities are expected to answer and meet the needs of the community about its infrastructure and environment, and have many positive impacts on the company, namely being able to maintain or boost its reputation in order to gain high public trust and be able to build a strong corporate brand identity, a company that has awareness of carrying out CSR activities properly deserves a wide opportunity and strong support to continue to carry out its business operations well, the commitment and support will come from various community stakeholders, local governments and shareholders.

CSR in the long term will provide a profitable business guarantee, not only increase public trust, strengthen investment, but the implementation of CSR activities will certainly secure the company's business operations so that the company can run operations without the constraints that arise from the nearest environment. Limited Liability Company Law No. 40 of 2007. Article 74 paragraph (1) reads as follows: "Companies that carry out their business activities in the field or related to Natural Resources are required to carry out Social Responsibility with the Environment" [1]. PT Indonesia Power Semarang Power Generation Unit, as a government company consciously responds positively to the government's 
recommendations or obligations. CSR activities are planned as part of the management strategies program, not only activities to show the public have done CSR activities, but the allocation of assistance provided must really be able to help overcome infrastructure and environmental problems and create target independence.

As a company with high intentions and seriousness, and aware of the position of using the area of operation area of Semarang City Business, PT Indonesia Power Semarang Power Generation Unit is committed to helping to overcome poverty alleviation by helping provide capital facilities, infrastructure assistance and needs for the community environment. The CSR target is in Gunungpati Sub-District which is one of the 16 sub-districts in Semarang, demographic data shows the poverty rate in this area is relatively high. As quoted from the results of research conducted by the Research and Community Service Institute Unisbank Semarang (2008) The profile of the poor in 4 districts of Pedurungan, North Semarang, West Semarang and Gunungpati is as follows: the types of jobs include workers, self-employed and fishermen, with a large income below Rp. 500.000, - per month. Age includes productive age, number of family members $2-5$ people, low level of education that is to graduate from elementary school, use water from wells, use electricity, the need for housing is fulfilled by themselves, do not own land and people in the surrounding environment work as laborers.

CSR programs can take many forms, including philanthropy-caricature, corporate advocacy on social issues, partnerships with advocacy groups, and ongoing business practices [2]. A recent study by Cone (2013) found that CSR has become more than a good strategy for business; CSR is now assessed as a form of activity that answered the expectations of businesses and communities. Companies are expected to carry out CSR activities with a focus on more complex issues, including socio-political issues and environmental issues.

In CSR there are also activities that are caritative-philanthropic, namely providing the needs of community infrastructure to support social economic mobility as well as various community businesses, in addition to providing assistance providing the needs of the community to improve the daily quality of life of its people.

Evaluation in the form of analysis will be a means to provide quality reporting to the government about the activities carried out, whether the activity is able to have a major impact and benefit for the development and development of the local socioeconomic. CSR activity implementation report also needs to be prepared systematically and well, the report displays and analyzes data and achievements accurately related to the provision of infrastructure and environmental needs of the community. Not only does it feature writing from the perspective of the beneficiary, but also from the beneficiary. How is CSR activity implemented in the context of the quality of infrastructure needs and community environmental needs, at PT Indonesia Power UP Semarang?

\section{Research Method}

This research was conducted with a Descriptive-Quantitative approach through the Survey method by disseminating a questionnaire containing structured answers. Next get an answer quantified by numbers and percentages designed into a pie chart. The population are citizen in Gunungpati, Semarang city, and samples are they received aids infrastructure and environmental needs from CSR PT Indonesia Power Semarang. Unit of analysis in this research CSR programmed specifically infrastructure and environmental needs to the citizen. 


\section{Results and Discussion}

In this discussion will focus on the evaluation seen from the indication of response, namely acceptance support for the CSR activities of PT Indonesia Power Semarang in Gunungpati District. CSR activities are in the form of two things, namely providing assistance in providing public infrastructure needs and community environmental needs.

\subsection{Public Infrastructure Needs}

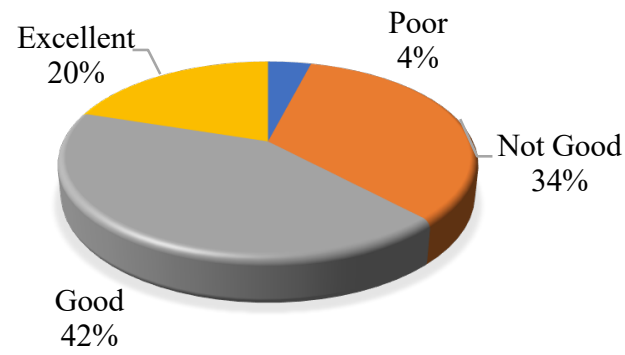

Fig. 1. Response to The Provision of Assistance for Places and Tools of Worship.

The above data indicates that CSR activities in the form of assistance in the provision of places and tools of worship in the community get a good response and even very good. This means that most people support and accept the gift in order to increase the activities of religious rituals in daily life. However, there are still those who consider such a gift not good (34 percent), because it is judged not to educate the public.

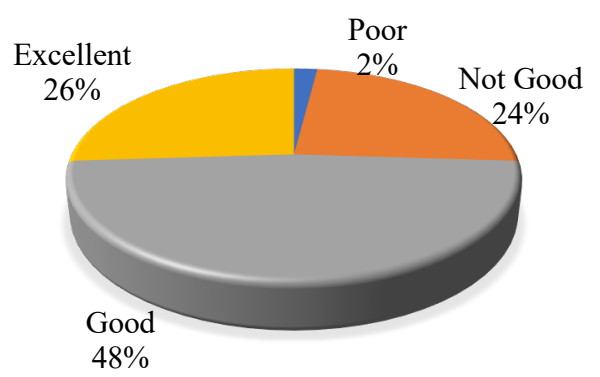

Fig. 2. Response to Public Infrastructure Assistance (Procurement of Marker Candle Monument).

Research on CSR activities also shows that most of the target community activities provide acceptance support to public infrastructure assistance that is intended to procure a marker candle monument in the middle of the village. 


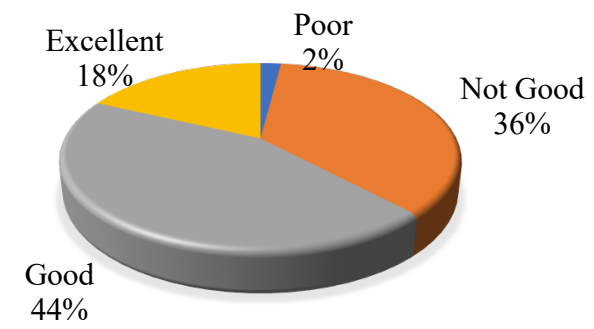

Fig. 3. Response to Arts Facilities and Places of Activity.

Based on the results of the research, it can be known that most of the community accepts and supports CSR assistance in the form of providing tools for arts activities such as; traditional clothes, tambourans and drums. Because it is considered to increase the spirit of Gunungpati Community in the activities of the company.

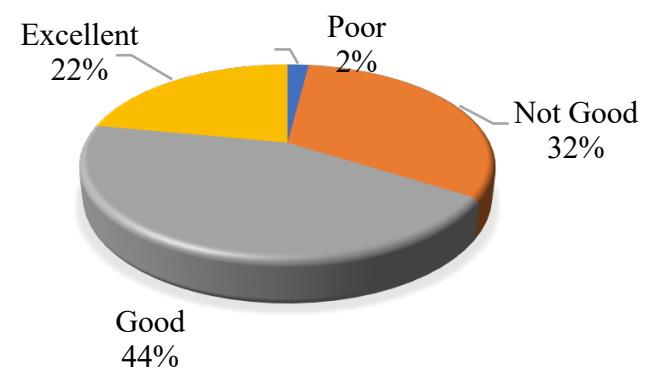

Fig. 4. Response to Balai Warga Building Facility Assistance.

The response to the granting of facilities of the community hall in Gunungpati was found to have the support of the reception of most members of the community. This is because of the perceived benefits of building facilities as a meeting place or activity in the region.

\subsection{Community Environmental Needs}

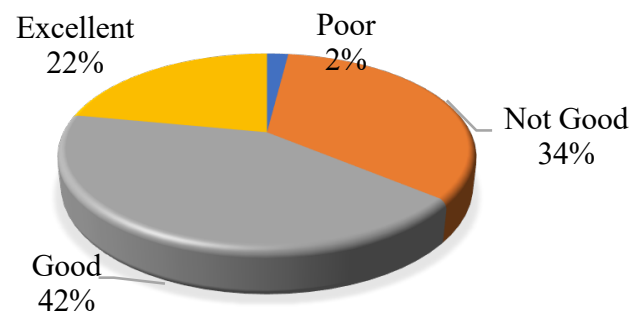

Fig. 5. Response to Garbage Disposal. 


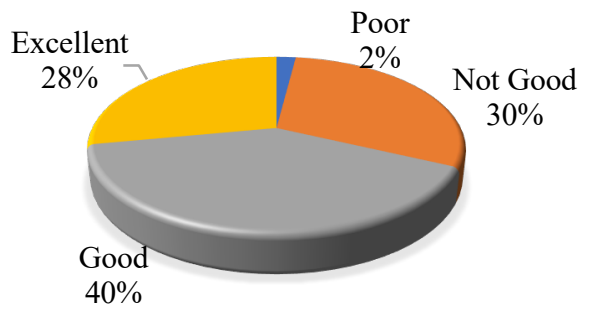

Fig. 6. Response to Local Waste Management Installation Assistance.

The description of the data above is to show most communities can receive assistance providing garbage cans. This is in order to support clean and tidy village programs.

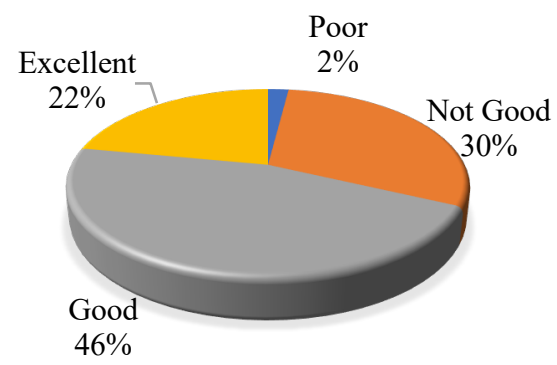

Fig. 7. Response to The Initiation of The Establishment of Environmental Care Society.

The results also describe most communion members supporting and receiving assistance with local waste management installations.

The activities of CSR in the form of empowering the community through the initiation of the establishment of the Environmental Care Society also spread acceptance support from most communities.

\section{Conclusion}

In conclusion, it can be conveyed that: First, the results of the analysis show most members of the community or communities targeted by PT Indonesia Power Semarang CSR activities in the District of Gunungpati Semarang, can receive and support (receiving and supporting) the provision of public infrastructure needs and community environmental needs. This is considered to be a form of concern for state-owned enterprises towards efforts to improve the socioeconomic life of the people around the company.

Second, PT Indonesia Power Semarang's CSR activities that are intended to provide assistance providing infrastructure needs and community environment need to continue (sustainability programs) because people still feel in need, as a result of socioeconomic conditions that are still relatively low in Semarang City.

Third, if there is still a response from some community members who assess the provision of assistance providing infrastructure and environmental needs, it is a misjudged activity by 
arguing that this form of assistance is not going to educate and is far from self-reliance on community members. It also shows that there are still members of the community who are critical of PT Indonesia Power Semarang's CSR activities.

Fourth, PT Indonesia Power Semarang's CSR activities in Gunungpati sub-district still need to balance caritative-philanthropic activities with consultative-empowering assistance to communities and social groups that care about their community environment in an effort to empower the community.

\section{References}

[1] T. K. Rahmatullah, "Panduan praktis pengelolaan CSR," Yogyakarta Samudra Biru, 2011.

[2] P. Kotler and N. Lee, "Best of breed: When it comes to gaining a market edge while supporting a social cause,'corporate social marketing' leads the pack," Soc. Mar. Q., vol. 11, no. 3-4, pp. 91-103, 2005. 